\title{
Apolipoprotein-J blocks increased cell injury elicited by ox-LDL via inhibiting ROS- CaMKII pathway
}

\author{
Yanzhuo Ma', Zhi Gong ${ }^{1}$, Kai Nan², Shuying Qi', Yu Chen', Chao Ding ${ }^{1}$, Dongmei Wang ${ }^{1}$ and Leisheng Ru ${ }^{1 *}$
}

\begin{abstract}
Background: Oxidized low-density lipoprotein (ox-LDL) is crucial in cardiac injury. Apolipoprotein-J (ApoJ) contributes to antiapoptotic effects in the heart. We aimed to evaluate the protective effects of ApoJ against oxLDL cytotoxicity in Neonatal rat ventricular cells (NRVCs).

Methods and results: NRVCs were damaged by exposure to ox-LDL, as shown by increased caspase-3/7 activity, enhanced caspase-3 expression, and decreased cell viability. ApoJ overexpression, using an adenovirus vector, significantly reduced ox-LDL-induced cell injury. ApoJ also prevented ox-LDL from augmenting reactive oxygen species (ROS) production, as demonstrated by elevated Nox2/gp91 ${ }^{\text {phox }}$ and P47 expression. Furthermore, ApoJ overexpression reduced CaMKII $\delta$ expression elicited by ox-LDL in cultured NRVCs. Upregulating CaMKII $\delta$ activity, mediated by ox-LDL, was significantly inhibited by ApoJ overexpression. A CaMKII $\delta$ inhibitor, KN93, prevented ApoJ's protective effect against ox-LDL cytotoxicity. A ROS scavenger, Mn (III)meso-tetrakis (4-benzoic acid) porphyrin (Mn (III)TBAP), also attenuated CaMKIII's increased expression and activity, induced by ox-LDL, and showed similar results to ApoJ by attenuating ox-LDL-induced cell damage, as ApoJ did.
\end{abstract}

Conclusions: ApoJ confers cytoprotection to NRVCS against ox-LDL cytotoxicity through the ROS-CaMKIl pathways.

Keywords: Ox-LDL, Apolipoprotein-J, Apoptosis, Neonatal rat ventricular cells

\section{Background}

Apolipoprotein-J (ApoJ) is a multifunctional glycoprotein widely present in tissues and body fluids. ApoJ expression is upregulated in acute myocardial infarction, atherosclerosis, myocarditis, oxidative stress, inflammation, and after injury in general [1]. Apo's function is thought to limit tissue injury and/or promote tissue remodeling.

ApoJ has cytoprotective properties [2, 3], and its overexpression benefits injured blood vessels by inhibiting migration, adhesion, and proliferation of smooth muscle cells. In addition, blocking secreted ApoJ leads to increased apoptosis of neuroblastoma cells induced by the chemotherapeutic drug doxorubicin [4]. In the heart, ApoJ produces cardioprotective effects on ischemically challenged $\mathrm{H} 9 \mathrm{C} 2$ cells and isolated adult ventricular rat cardiomyocytes after ischemia-induced death [5]. Furthermore,

\footnotetext{
* Correspondence: muyeqiufeng2008@163.com

'Department of Cardiology, Bethune International Peace Hospital, 398,

Zhongshan Road, Shijiazhuang 050082, Hebei, China

Full list of author information is available at the end of the article
}

ApoJ-deficient mice show more impaired cardiac function and worse myocardial scarring compared to wild-type mice. Thus, ApoJ may play a critical role in reducing injury to both normal and diseased cells.

Oxidized LDL (ox-LDL) is an independent risk factor in cardiovascular heart disease (CHD), which has various deleterious cellular effects such as intracellular calcium-content alteration, necrosis, and apoptosis. In the present study, we aimed to determine whether ApoJ overexpression contributes to antiapoptotic effects in the heart against ox-LDL-induced cell injury and to clarify the underlying mechanisms.

\section{Methods}

\section{Animals}

Neonatal Sprague-Dawley (SD) rats were obtained from the Department of Experimental Animals of Hebei University (Shijiazhuang, Hebei, China).

(c) The Author(s). 2019 Open Access This article is distributed under the terms of the Creative Commons Attribution 4.0 International License (http://creativecommons.org/licenses/by/4.0/), which permits unrestricted use, distribution, and reproduction in any medium, provided you give appropriate credit to the original author(s) and the source, provide a link to the Creative Commons license, and indicate if changes were made. The Creative Commons Public Domain Dedication waiver (http://creativecommons.org/publicdomain/zero/1.0/) applies to the data made available in this article, unless otherwise stated. 


\section{Myocyte isolation and cell culture}

Single ventricular myocytes were obtained by enzymatic dissociation using collagenase (type II) and pancreatin, as described previously, albeit with some modifications [6]. We did not use the discontinuous Percoll gradient, and the differential adhesion time was $1.5 \mathrm{~h}$ instead of overnight. Ventricular myocardial cells from neonatal SD rats (aged 1 d; Hebei Medical University) were homogenized and dissociated with collagenase II and pancreatin six times, for $20 \mathrm{~min}$ at each time point. The first cell suspension was discarded to remove other cells, such as erythrocytes and fibroblasts, while the rest of the cell suspensions were washed with FBS, mixed in $10-\mathrm{cm}$ plates, and incubated for $1.5 \mathrm{~h}$, allowing cardiomyocyte enrichment by differential adhesion. The supernatant was then plated onto a new dish with DMEM containing $10 \%$ FBS at $37^{\circ} \mathrm{C}$. Neonatal rat ventricular cells (NRVCs) were then given different treatments. Ox-LDL was purchased from Solarbio Company (Beijing, China) and oxidized using copper sulfate. LDL oxidation was performed by incubating it with $\mathrm{Cu}_{2} \mathrm{SO}_{4}$ (oxidant) in PBS at $37^{\circ} \mathrm{C}$ for $20 \mathrm{~h}$. The oxidation process was terminated by adding excess EDTA-Na $\mathrm{Na}_{2}$. Each lot was analyzed, using agarose gel electrophoresis, for migration against LDL. This lot of ox-LDL migrated two-fold further than the native LDL.

\section{Adenoviral infection of NRVCs}

ApoJ-expressing adenovirus was generated using the pAD-ApoJ-IRES-EGFP adenoviral vector. Adenovirus generated from pAD-IRES-EGFP was used as control, and the adenoviral vectors were synthesized using the Gateway Cloning System (Invitrogen). Isolated NRVCs were infected with the indicated adenoviruses at a multiplicity of infection of 200 with serum-free DMEM. After $4 \mathrm{~h}$, the supernatant was removed and replaced with DMEM containing 10\% FBS. After $36 \mathrm{~h}$, the supernatant was again removed, and the NRVCs were given different treatments.

\section{3-(4,5-Dimethylthiazol-2-yl)-2,5-diphenyltetrazolium bromide (MTT) assay}

Cell viability was measured using the MTT assay (Sigma, St. Louis, MO, USA). The cells $\left(2 \times 10^{4}\right.$ cells $\left./ \mathrm{ml}\right)$ were cultured in 96-well plates in complete medium for $24 \mathrm{~h}$. Then, the medium was replaced with fresh medium containing $0.5 \%$ FBS, and the cells were given different treatments. After the treatments, $20 \mu \mathrm{L}$ of MTT, at a concentration of $5 \mathrm{mg} / \mathrm{mL}$, was added, and the cells were incubated for $4 \mathrm{~h}$. Thereafter, the medium was discarded, and $150 \mu \mathrm{L}$ of DMSO was added for $10 \mathrm{~min}$. Absorbance at $570 \mathrm{~nm}$ was measured for each well using an ELISA microplate reader. All assays were performed in triplicate and repeated three times.

\section{Caspase-3/7 activity assay}

Apo-ONE Homogeneous Caspase-3/7 Assay (Promega, Madison, WI, USA) was used to measure apoptosis in the NRVCs. Briefly, the cells were plated in 96-well plates at a density of $10^{4}$ cells/well, and were given different treatments. Then, $100 \mu \mathrm{L}$ of Apo-ONE Homogeneous Caspase-3/7 Reagent was added to each well. The plate was incubated for $1 \mathrm{~h}$ at room temperature, using a plate shaker, at $350 \mathrm{rpm}$. Subsequently, fluorescence was measured using a fluorometer with excitation at $499 \mathrm{~nm}$ and emission at $521 \mathrm{~nm}$. All assays were performed in triplicate and repeated three times.

\section{CaMKII activity assay}

The CAMKII Elisa kit (BlueGene) was used to measure CaMKII activity in NRVCs. Briefly, the cells were given different treatments and lysed. Then $100 \mu \mathrm{L}$ of standards or samples were added to the antibody pre-coated Microtiter Plate, with $100 \mu \mathrm{l}$ PBS added to the blank control well. We dispensed $10 \mu \mathrm{l}$ of balance solution, only into samples, and mixed it well. Then we added $50 \mu \mathrm{l}$ of Conjugate to each well (not the blank control wells) and mixed it well. Then the plate was incubated for $1 \mathrm{~h}$ at $37^{\circ} \mathrm{C}$. After washing five times, we added $50 \mu \mathrm{L}$ Substrate A and B to each well, including the blank control well. The wells were covered and incubated for 10-15 min at $37^{\circ} \mathrm{C}$. Finally, we added $50 \mu \mathrm{L}$ of stop solution to each well, including the blank control well. We determined the OD at $450 \mathrm{~nm}$ using a microplate reader immediately. All assays were performed in triplicate and repeated three times.

\section{Immunoblotting}

After rinsing in cold PBS three times, the cells were homogenized in RIPA buffer. The supernatant was then centrifuged at $120,000 \times g$ for $15 \mathrm{~min}$ at $4{ }^{\circ} \mathrm{C}$. The samples $(10-20 \mathrm{mg})$ were run on SDS-PAGE gels, transferred to PVDF filter membranes, and used for western blotting with monoclonal antibodies against CaMKII $\delta$ (Santa Cruz Biotechnology, Santa Cruz, CA, USA), p47 $7^{\text {phox }}$, Nox2/gp91 ${ }^{\text {phox }}$ (Abcam, Cambridge, MA, USA), cleaved caspase-3 (Asp175) (Cell Signaling Technology), and ApoJ (EterLife, Birmingham, UK). The PVDF membranes were then incubated with HRP-conjugated anti-rabbit immunoglobulin $G$ antibody (Santa Cruz Biotechnology, Santa Cruz, CA, USA) for $1 \mathrm{~h}$. The blot was developed with an ECL-Plus chemiluminescence reagent kit and visualized with the UVP Bio-Imaging System. The blot densities were analyzed using Image J.

\section{Statistics}

All values in the text and figures are presented as means \pm SD of $\mathrm{n}$ independent experiments. All data (except western blotting density) were fed to ANOVA, followed by a Bonferroni correction for post hoc tests. Western blot densities were analyzed with the Kruskal-Wallis test, followed by Dunn's post hoc tests. $P<0.05$ was considered statistically significant. 


\section{Results}

ApoJ overexpression prevented cell injury induced by oxLDL

To determine whether ApoJ attenuated cell injury induced by ox-LDL, the NRVCs were infected with recombinant adenovirus with and without ApoJ. Compared to the control adenovirus-infected cells, ApoJ expression increased significantly in the Ad-ApoJ-infected NRVCs (Fig. 1a). Next, we analyzed the effect of ApoJ in relation to ox-LDL-induced cell injury. Ox-LDL was added into the NRVCs $36 \mathrm{~h}$ after adenovirus infection. As shown in Fig. 1b, ox-LDL administration enhanced cleaved caspase-3 expression, which was markedly attenuated by ApoJ overexpression, as evidenced by the immunoblotting assay. Similar results are seen in Fig. 1c and d-exposure to ox-LDL significantly decreased cell viability, while ApoJ overexpression markedly prevented decreased cell

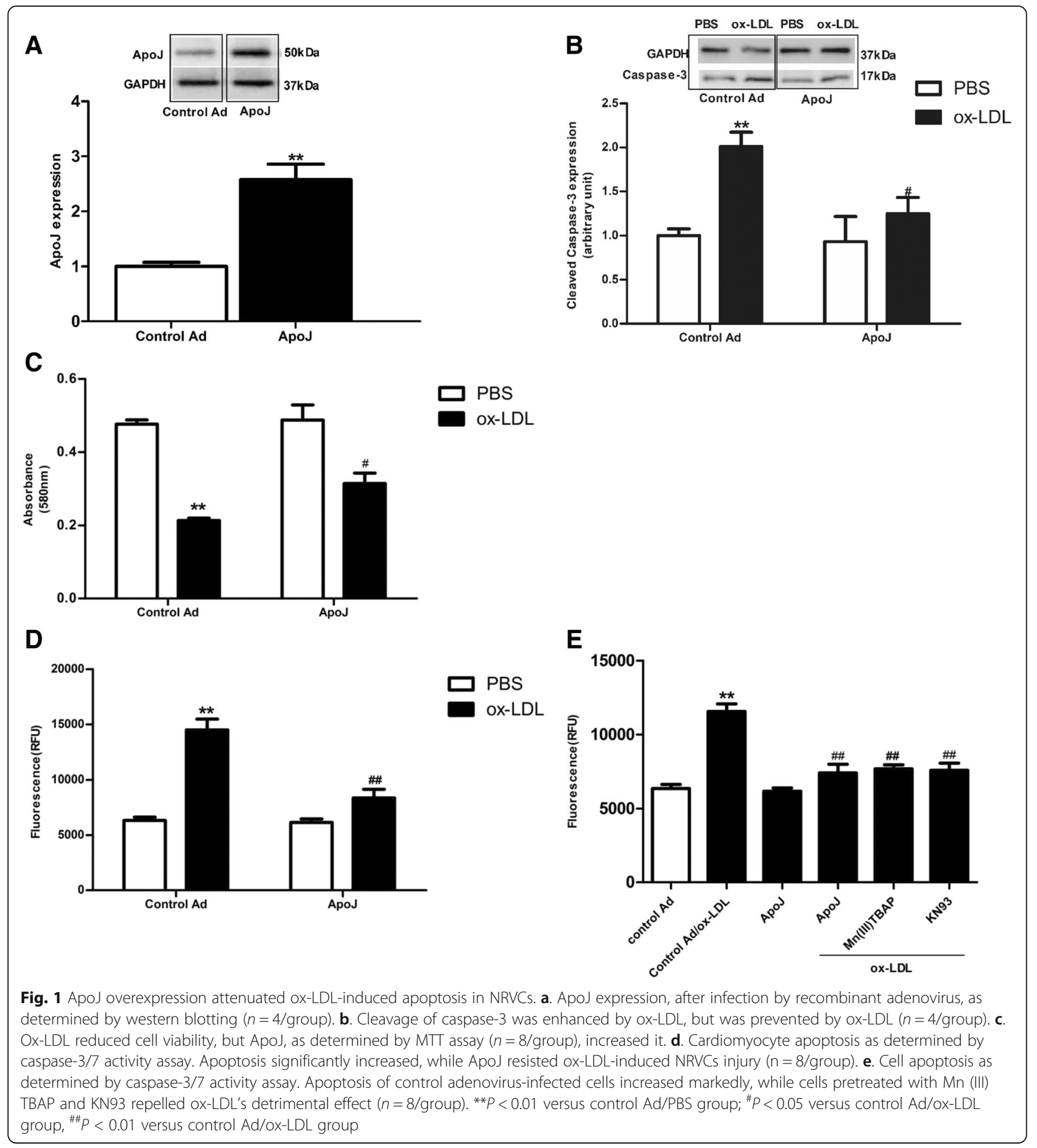


viability induced by ox-LDL (Fig. 1c). Furthermore, ox-LDL increased the percentage of apoptotic cardiomyocytes, which were markedly reduced by ApoJ overexpression (Fig. 1d). These results suggest that ApoJ conferred prominent resistance to cell injury induced by ox-LDL.

Then, we analyzed the ox-LDL downstream inducers, which might mediate cell injury and might be mediated by ApoJ to prevent ox-LDL induced-injury. We used a CAMKII inhibitor [KN93] and a ROS scavenger [Mn (III)TABP] [7] in the presence of ox-LDL. As shown in Fig. 1e, Mn (III) TBAP and KN93 markedly decreased the percentage of apoptotic cells induced by ox-LDL. These results indicate that ox-LDL stimulates cell apoptosis through the CaMKII and ROS pathways.

\section{ApoJ prevented ROS activation}

To check whether the antiapoptotic pathway employed by ApoJ involved ROS activation, we analyzed the Nox2/ gp91 ${ }^{\text {phox }}$ expression levels. Ox-LDL induced higher Nox2/ gp91 ${ }^{\text {phox }}$ expression than that in the control adenovirus-infected cells, and the increased Nox2/gp91 ${ }^{\text {phox }}$ expression was significantly attenuated by ApoJ (Fig. 2a). Similar results are seen in Fig. $2 b-p 47^{\text {phox }}$ expression, stimulated by ox-LDL administration, while ApoJ attenuated the increased $\mathrm{p} 47^{\text {phox }}$ expression induced by ox-LDL. These results hint at ApoJ-mediated inhibition of ox-LDL-induced ROS production in NRVCs.

\section{ApoJ overexpression attenuated CaMKII activity and expression caused by ox-LDL}

To investigate whether ApoJ protects NRVCs through the CaMKII pathway, we measured CaMKII activity. As shown in Fig. 3a, ox-LDL administration markedly enhanced CaMKII $\delta$ expression compared to that in the control adenovirus-infected cells, while ApoJ overexpression significantly prevented ox-LDL-stimulated CaMKII $\delta$ expression. Similar results are seen in Fig. 3b; ox-LDL administration increased CaMKII activity, while ApoJ overexpression decreased the CaMKII activity caused by ox-LDL. The increased CaMKII activity, caused by ox-LDL, was attenuated by Mn (III) TBAP, suggesting that ROS may be the upstream activators of CaMKII (Fig. 3c). To further elucidate the underlying pathway responsible for Apol's protective effect on NRVCs, ApoJ-overexpressing cells were treated with exogenous $\mathrm{H}_{2} \mathrm{O}_{2}$, which showed that $\mathrm{H}_{2} \mathrm{O}_{2}$ markedly enhanced CaMKII expression and activity while ApoJ decreased it (Fig. 3d and e).

\section{Discussion}

We thus successfully demonstrated that ApoJ attenuated ox-LDL-induced NRVC apoptosis. In addition, we found that the cardioprotection exerted by ApoJ against ox-LDL may be mediated through the ROS-CaMKII pathway.

Plasma high-density lipoprotein (HDL) levels are inversely proportional to CHD risk. ApoJ is associated with HDL subclasses, implying that ApoJ's beneficial effect is linked to HDL. ApoJ, a circulating glycoprotein, can be induced by injury such as atherosclerosis and myocardial infarction [8, 9]. Moreover, it has been demonstrated that, in addition to being necessary for cell survival, ApoJ is associated with cell apoptosis and is also expressed in apoptosis-resistant cells [10-14]. Methoxyacetic acid (MAA) administration induces ApoJ located in the cytoplasm, thus exerting protection
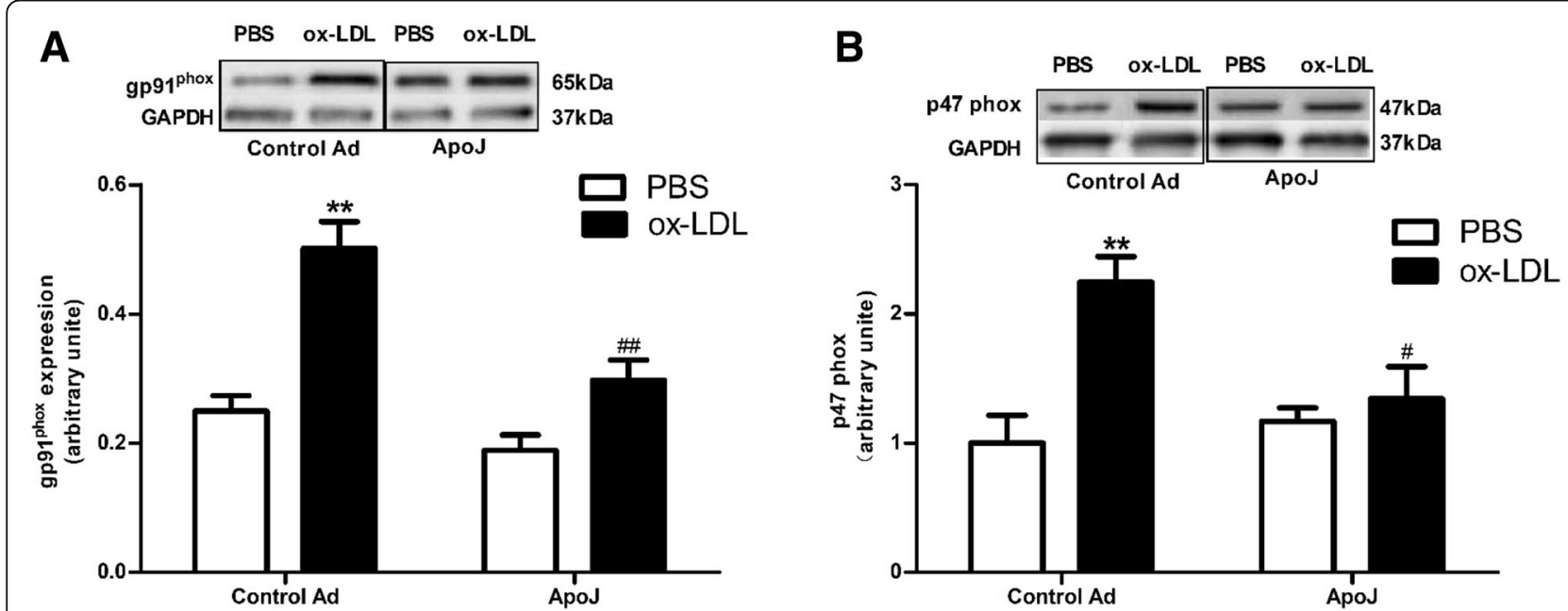

Fig. 2 ApoJ attenuated the ox-LDL-stimulated ROS production. a. Nox2/gp91 ${ }^{\text {phox }}$ expression in NRVCs, as determined by western blotting. Ox$\mathrm{LDL}$ enhanced Nox2/gp91 ${ }^{\text {phox }}$ expression in control adenovirus-infected cells, which was attenuated by ApoJ-overexpression ( $\left.n=4 / \mathrm{group}\right)$. b. Nox $2 / p 47^{\text {phox }}$ expression, as determined by western blotting ( $n=4 /$ group). Ox-LDL increased Nox $/$ p4 $7^{\text {phox }}$ expression in control adenovirusinfected NRVCs, while ApoJ overexpression prevented Nox $2 / p 47^{\text {phox }}$ expression. ${ }^{*} P<0.05$ versus control Ad/PBS group, ${ }^{* *} P<0.01$ versus control Ad/PBS group; ${ }^{\# P}<0.05$ versus control Ad/ox-LDL group, ${ }^{\# \#} P<0.01$ versus control Ad/ox-LDL group 


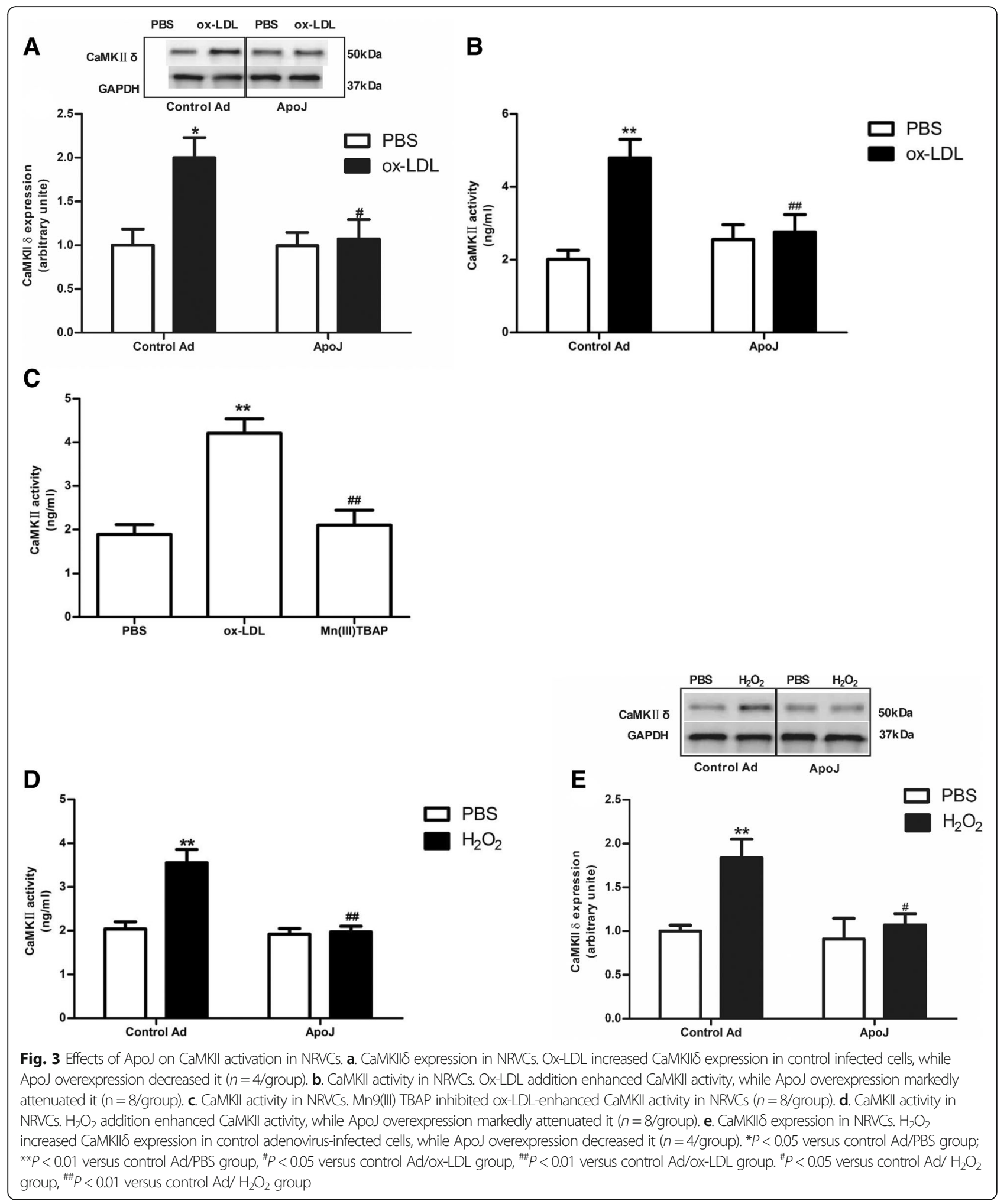

against apoptotic cell death [15]. ApoJ overexpression protects cells from apoptosis [12, 13], and ApoJ biosynthesis blocks increased cell apoptosis in vitro. ApoJ also delays apoptosis [16] and limits auto-immune autocarditis severity [17]. ApoJ deficiency could worsen brain damage after neonatal hypoxia-ischemia. Therefore, ApoJ may serve as an antioxidative agent, protecting cells from apoptosis caused by ROS [14]. 
Here, we overexpressed ApoJ in NRVCs to determine whether elevated ApoJ prevented ox-LDL cytotoxicity and attempted to unravel the downstream activator responsible for these effects. We found that ApoJ overexpression increased cell viability and decreased apoptosis compared to the control cells. Moreover, we found that CaMKII inhibitors and ROS scavengers exerted cardioprotective effects on NRVCs in the presence of ox-LDL, similar to the effects afforded by ApoJ. This suggested that CaMKII and ROS may participate in the signaling pathways regulating ApoJ's effects on cell injury induced by ox-LDL.

Apoptosis occurs in many processes through multiple pathways [18]. Gp91phox was the membrane subunit and p47phox was the cytosolic subunit associated with NOX2, which was a subunit of the NADPH oxidase. It has been reported that increased expression of gp91phox and p47phox contribute to ROS overproduction $[19,20]$. Enhanced ROS production could cause cell apoptosis, thus initiating pathological processes. Jun et al. [21] discovered that ApoJ significantly attenuated $\mathrm{H}_{2} \mathrm{O}_{2}$-induced cardiomyocyte apoptosis. ApoJ has also been reported to decrease intracellular ROS levels in human corneal endothelial cells and retinal pigment epithelial cells [22, 23]. We have previously shown that adenovirus-mediated ApoJ overexpression abrogates the elevated ROS production induced by AngII, as determined by reduced Nox $2 / \mathrm{gp} 91^{\text {phox }}$ expression in NRVCs. This indicates downstream ROS pathways may take part in ApoJ's antiapoptotic mechanisms. In the present study, we discovered ApoJ overexpression, mediated by the adenovirus, attenuated the increased ROS production caused by ox-LDL, as evidenced by decreased Nox2/gp91 $1^{\text {phox }}$ and $\mathrm{P} 47^{\text {phox }}$ expression in the NRVCs. These results suggest that ROS is a downstream agent regulating ApoJ's antiapoptotic effects caused by ox-LDL. However, the underlying mechanisms by which the elevated ROS cause the detrimental effects remain largely unknown.

Calcium $(\mathrm{Ca} 2+)$ /calmodulin ( $\mathrm{CaM})$-dependent protein kinase II (CaMKII) may serve as a ROS sensor in the heart [24]. CaMKII is now considered a key enzyme in cardiac disease pathologies, such as myocardial infarction, heart failure, and malignant arrhythmias [25, 26]. There are four main posttranslational modifications that regulate the CaMKII activity maintenance independent of the $\mathrm{Ca} 2$ +/calmodulin-binding-autophosphorylation [27, 28], oxidation [25, 29, 30], O-linked N-acetylglucosamination [31], and S-nitrosylation [32]. CaMKII is ubiquitously expressed and acts as a multifunctional protein kinase with four isoforms, $\alpha, \beta, \gamma$, and $\delta$. $\alpha$ and $\beta$ isoforms are predominantly expressed in the brain, where they play a critical role in neuronal function. $\gamma$ and $\delta$ isoforms are mainly expressed in the heart. Cardiac CaMKII expression and activity are increased in CHD, and elevated CaMKII activity augments CHD severity.
In vivo and in vitro studies have demonstrated that sustained CaMKII activation induces cell death, and CaMKII inhibition relieves cell injury induced by processes such as endoplasmic reticulum stress and oxidative stress. In our study, we found that ox-LDL significantly enhanced CaMKII expression and activity in NRVCs, which were abrogated by ApoJ overexpression. Furthermore, co-treatment with a CaMKII inhibitor or ROS scavenger prevented ox-LDL-elicited CaMKII activity and expression, suggesting that ROS may be upstream activators of CaMKII in terms of regulating NRVC apoptosis caused by ox-LDL. To further analyze the role of ROS in this process, we treated NRVCs with $\mathrm{H}_{2} \mathrm{O}_{2}$. Our results showed that CaMKII activity and CaMKII $\delta$ expression were markedly augmented in contrast to the control adenovirus-infected cells. In addition, $\mathrm{H}_{2} \mathrm{O}_{2}$-induced CaMKII activation was prevented by ApoJ overexpression.

\section{Conclusions}

Increased ROS production, caused by ox-LDL-induced CaMKII activation, may occur through posttranslational oxidation modification, and ApoJ exerts its cardioprotection by inhibiting the ROS-CaMKII pathway.

\section{Study limitations}

ApoJ contains an antiparallel, disulfide-linked heterodimer comprising an $\alpha$-chain and a $\beta$-chain. The $\alpha$ - and $\beta$-subunits are linked by five closely spaced disulfide bonds, enabling the protein to self-associate and form higher oligomers to further improve protein homeostasis. However, those disulfide bonds may be not adequately established in the overexpressed ApoJ, Those cysteines not involved in disulfide bonds may act as ROS scavengers [33]. In this case, the function of ApoJ is compromised. We intend to further investigate the disulfide bond's stability in the future.

\section{Abbreviations \\ ApoJ: Apolipoprotein-J; CaMKII: Calcium (Ca2+)/calmodulin (CaM)-dependent protein kinase II; CHD: Cardiovascular heart disease; HDL: High density lipoproteins; NRVCs: Neonatal rat ventricular cells; ox-LDL: Oxidized low- density lipoprotein; ROS: Reactive oxygen species; SD: Sprague-Dawley}

\section{Acknowledgements \\ Dr. Sheng Jin is acknowledged for research support. \\ Funding \\ None. \\ Availability of data and materials \\ Corresponding author can be contacted for that.}

Authors' contributions

KN and ZG carried out the molecular studies. YM and DW made substantial contributions to the design and drafted the manuscript. CD, YC and SQ carried out the immunoassays. LR participated in the design of the study and performed the statistical analysis. All authors read and approved the final manuscript 


\section{Ethics approval and consent to participate}

Our study was approved by the Animal Care and Use Committee at Bethune International Peace Hospital (Shijiazhuang, Hebei, China). The experiment was carried out in accordance with the Code of Ethics of the World Medical Association (Declaration of Helsinki).

\section{Consent for publication}

No such data included.

\section{Competing interests}

The authors declare that they have no competing interests.

\section{Publisher's Note}

Springer Nature remains neutral with regard to jurisdictional claims in published maps and institutional affiliations.

\section{Author details}

'Department of Cardiology, Bethune International Peace Hospital, 398, Zhongshan Road, Shijiazhuang 050082, Hebei, China. ${ }^{2}$ Health and Medical Development Research Center of Hebei Province, Shijiazhuang, Hebei, China.

Received: 13 September 2018 Accepted: 14 May 2019

Published online: 22 May 2019

\section{References}

1. Klock G, Storch S, Rickert J, Gutacker C, Koch-Brandt C. Differential regulation of the clusterin gene by ha-ras and c-myc oncogenes and during apoptosis. J Cell Physiol. 1998;177:593-605.

2. Kogel D, Concannon CG, Muller T, Konig H, Bonner C, Poeschel S, et al. The APP intracellular domain (AICD) potentiates ER stress-induced apoptosis. Neurobiol Aging. 2012;33:2200-9.

3. Schwarz M, Spath L, Lux CA, Paprotka K, Torzewski M, Dersch K, et al. Potential protective role of apoprotein $J$ (clusterin) in atherogenesis: binding to enzymatically modified low-density lipoprotein reduces fatty acidmediated cytotoxicity. Thromb Haemost. 2008;100:110-8.

4. Cervellera M, Raschella G, Santilli G, Tanno B, Ventura A, Mancini C, et al. Direct transactivation of the anti-apoptotic gene apolipoprotein $J$ (clusterin) by B-MYB. J Biol Chem. 2000;275:21055-60.

5. Krijnen PA, Cillessen SA, Manoe R, Muller A, Visser CA, Meijer CJ, et al. Clusterin: a protective mediator for ischemic cardiomyocytes? Am J Physiol Heart Circ Physiol. 2005;289:H2193-202.

6. Wollert KC, Taga T, Saito M, Narazaki M, Kishimoto T, Glembotski CC, et al. Cardiotrophin-1 activates a distinct form of cardiac muscle cell hypertrophy. Assembly of sarcomeric units in series VIA gp130/leukemia inhibitory factor receptor-dependent pathways. J Biol Chem. 1996;271:9535-45.

7. Hund TJ, Mohler PJ. Role of CaMKII in cardiac arrhythmias. Trends in cardiovascular medicine. 2015;25:392-7.

8. Rosenberg ME, Silkensen J. Clusterin and the kidney. Exp Nephrol. 1995;3:9-14.

9. Silkensen JR, Schwochau GB, Rosenberg ME. The role of clusterin in tissue injun. Biochemistry and cell biology = Biochimie et biologie cellulaire. 1994;72:483-8.

10. Koch-Brandt C, Morgans C. Clusterin: a role in cell survival in the face of apoptosis? Prog Mol Subcell Biol. 1996;16:130-49.

11. Sintich SM, Steinberg J, Kozlowski JM, Lee C, Pruden S, Sayeed S, et al. Cytotoxic sensitivity to tumor necrosis factor-alpha in PC3 and LNCaP prostatic cancer cells is regulated by extracellular levels of SGP-2 (clusterin). Prostate. 1999;39:87-93.

12. Humphreys D, Hochgrebe TT, Easterbrook-Smith SB, Tenniswood MP, Wilson MR. Effects of clusterin overexpression on TNFalpha- and TGFbetamediated death of L929 cells. Biochemistry. 1997;36:15233-43.

13. Sensibar JA, Sutkowski DM, Raffo A, Buttyan R, Griswold MD, Sylvester SR, et al. Prevention of cell death induced by tumor necrosis factor alpha in LNCaP cells by overexpression of sulfated glycoprotein-2 (clusterin). Cancer Res. 1995;55:2431-7.

14. Viard I, Wehrli P, Jornot L, Bullani R, Vechietti JL, Schifferli JA, et al. Clusterin gene expression mediates resistance to apoptotic cell death induced by heat shock and oxidative stress. The Journal of investigative dermatology. 1999:112:290-6.

15. Clark AM, Maguire SM, Griswold MD. Accumulation of clusterin/sulfated glycoprotein-2 in degenerating pachytene spermatocytes of adult rats treated with methoxyacetic acid. Biol Reprod. 1997;57:837-46.
16. Bailey RW, Aronow B, Harmony JA, Griswold MD. Heat shock-initiated apoptosis is accelerated and removal of damaged cells is delayed in the testis of clusterin/ApoJ knock-out mice. Biol Reprod. 2002;66:1042-53.

17. McLaughlin L, Zhu G, Mistry M, Ley-Ebert C, Stuart WD, Florio CJ, et al. Apolipoprotein $\mathrm{J} /$ clusterin limits the severity of murine autoimmune myocarditis. J Clin Invest. 2000;106:1105-13.

18. Sinha Hikim AP, Swerdloff RS. Hormonal and genetic control of germ cell apoptosis in the testis. Rev Reprod. 1999;4:38-47.

19. Satoh Jl, Kino Y, Yanaizu M, Tosaki Y, Sakai K, Ishida T, et al. Expression of gp91 phox and p22phox, catalytic subunits of NADPH oxidase, on microglia in Nasu-Hakola disease brains. Intractable \& rare diseases research. 2016;5:275-9.

20. Nagarkoti S, Dubey M, Awasthi D, Kumar V, Chandra T, Kumar S, et al. SGlutathionylation of p47phox sustains superoxide generation in activated neutrophils. Biochim Biophys Acta, Mol Cell Res. 2018;1865:444-54.

21. Jun H-O, Kim D-h, Lee S-W, Lee HS, Seo JH, Kim JH, et al. Clusterin protects H9c2 cardiomyocytes from oxidative stress-induced apoptosisviaAkt/GSK-3 $\beta$ signaling pathway. Exp Mol Med. 2011;43:53

22. Kim JH, Kim JH, Jun HO, Yu YS, Min BH, Park KH, et al. Protective effect of Clusterin from oxidative stress-induced apoptosis in human retinal pigment epithelial cells. Investigative Opthalmology \& Visual Science. 2010;51:561.

23. Shin YJ, Kim JH, Seo JM, Lee SM, Hyon JY, Yu YS, et al. Protective effect of clusterin on oxidative stress-induced cell death of human corneal endothelial cells. Mol Vis. 2009;15:2789-95.

24. Erickson JR, He BJ, Grumbach IM, Anderson ME. CaMKII in the cardiovascular system: sensing redox states. Physiol Rev. 2011;91:889-915.

25. Erickson JR, Joiner ML, Guan X, Kutschke W, Yang J, Oddis CV, et al. A dynamic pathway for calcium-independent activation of CaMKII by methionine oxidation. Cell. 2008;133:462-74.

26. Hudmon A, Schulman H. Structure-function of the multifunctional Ca2+/calmodulindependent protein kinase II. The Biochemical journal. 2002;364:593-611.

27. Zhang T, Zhang Y, Cui M, Jin L, Wang Y, Lv F, et al. CaMKIl is a RIP3 substrate mediating ischemia- and oxidative stress-induced myocardial necroptosis. Nat Med. 2016;22:175-82.

28. Maier LS, Bers DM. Role of Ca2+/calmodulin-dependent protein kinase (CaMK) in excitation-contraction coupling in the heart. Cardiovasc Res. 2007;73:631-40.

29. Anderson ME. Oxidant stress promotes disease by activating CaMKII. J Mol Cell Cardiol. 2015:89:160-7.

30. He BJ, Joiner ML, Singh MV, Luczak ED, Swaminathan PD, Koval OM, et al. Oxidation of CaMKII determines the cardiotoxic effects of aldosterone. Nat Med. 2011;17:1610-8.

31. Erickson JR, Pereira L, Wang L, Han G, Ferguson A, Dao K, et al. Diabetic hyperglycaemia activates CaMKII and arrhythmias by O-linked glycosylation. Nature. 2013;502:372-6.

32. Erickson JR, Nichols CB, Uchinoumi H, Stein ML, Bossuyt J, Bers DM. SNitrosylation induces both autonomous activation and inhibition of calcium/ calmodulin-dependent protein kinase II delta. J Biol Chem. 2015;290:25646-56.

33. Zhu Z, Ren Z, Fan X, Pan Y, Lv S, Pan C, et al. Cysteine protects rabbit spermatozoa against reactive oxygen species-induced damages. PLoS One. 2017;12:e0181110

\section{Ready to submit your research? Choose BMC and benefit from:}

- fast, convenient online submission

- thorough peer review by experienced researchers in your field

- rapid publication on acceptance

- support for research data, including large and complex data types

- gold Open Access which fosters wider collaboration and increased citations

- maximum visibility for your research: over $100 \mathrm{M}$ website views per year

At BMC, research is always in progress.

Learn more biomedcentral.com/submissions 